\title{
Factors Influencing the Utilisation of Maternal Health Services: The Perspective of Rural Women in Ghana
}

\author{
Anita Anima Daniels \\ Department of Public Administration and Health Services Management \\ P. O. Box LG 78, University of Ghana, Legon, Ghana \\ Tel: +233244986463Ｅ-mail: realanidan@yahoo.com

\begin{abstract}
Albert Ahenkan (Corresponding author)
Department of Public Administration and Health Services Management

P. O. Box LG 78, University of Ghana, Accra, Ghana.

Tel: +233246955818Ｅ-mail: aahenkan@ug.edu.gh
\end{abstract}

\begin{abstract}
Kwabena Adu Poku
Department of Public Administration and Health Services Management

P. O. Box LG 78, University of Ghana, Accra, Ghana.
\end{abstract}

Received: April 27, 2013 Accepted: May 13, 2013 DOI: 10.5296/jpag.v3i2.3468

\begin{abstract}
Maternal mortality is a global issue and WHO recommends the use of maternal health services to help improve the health of women and babies during pregnancy and childbirth. Considering global and national interest in improving maternal health and the fact that Ghana is still battling with reducing maternal mortality, understanding the factors affecting the use of maternal services in rural areas is crucial as the women are seen as more vulnerable due to inequity issues. This study sets to examine the factors that influence the utilisation of antenatal and delivery services among rural women in Ghana, focusing on individual and area factors. A descriptive cross sectional study was carried out in three rural communities using Akuapim North District of Ghana as a case study. The study adopted the quantitative approach. Structured interviews were used in data collection with the help of interview schedules. Two hundred and ninety-six (296) respondents were sampled using both probability and non probability techniques. Findings reveal that the use of the MHS is inadequate in relation to the WHO standards. Individual characteristics such as age, marital status and family size and the cost and time taken to a health facility were significantly
\end{abstract}


associated with all the maternal health outcomes. Poor access to vehicles hindered women from delivery in a health institution and getting assistance from trained medical personnels. However, no significant association was established between education of respondents and the maternal health outcomes. It is recommended that the Ministry of Health engages in inter-sectoral collaboration to help ensure health equity. Effective integration of TBAs in providing care is needed to help improve utilisation of maternal services in rural areas.

Keywords: Antenatal, determinants, maternal health, utilization

\section{Introduction}

Antenatal and delivery services are meant to monitor and ensure the safety of pregnant women and their babies in order to prevent and reduce the incidence of maternal morbidity and mortality. Globally, over 500,000 women die from pregnancy and childbirth each year and about $99 \%$ of these deaths occur in developing countries (WHO, 1996). Among the Millennium Development Goals is to reduce this menace by three quarters by the year 2015 . Some studies have shown that the uptake of maternal health services in developing countries has significant consequences for both the safe transition of the mother through pregnancy and child birth, and the survival and health of the child during early infancy (Magadi et al., 2000). Antenatal care presents an opportunity to evaluate the mother's overall condition, diagnose and treat infections, screen for anaemia and HIV/AIDS and prevent low birth weight (UNFPA, 2004). Thaddeus and Maine (1994) indicate that delivering at a place where adequate facilities have been provided has consistently been found to be associated with reducing maternal mortality. The United Nations (2005) therefore recognises professional care at birth as one of the key factors that can lower maternal mortality.

Several demographic and socio-economic factors have been found to be associated with the use of MHS. Education has been found to be associated with the use of MHS (Elo, 1992; Chakraborty et al., 2003). Maternal age has been identified as a factor (Elo, 1992; Sharma et al., 2007; Magadi et al, 2007). Several studies have found a strong association between birth order and use of health care services (Wong et al., 1987; Elo, 1992). Sharma et al. (2007) and Magadi et al. (2000) lay emphasis on the employment status of women. The educational level of husbands has been found to be associated with the use of MHS (Shariff and Singh, 2002). Paul and Rumsey (2002) identify place of residence to have an influence on the use of MHS. Rahaman et al., (1982) found that geographical distance was one of the most important determinants of health care service utilization in rural areas.

Though the importance of utilising maternal health services has been barbed as a panacea to curbing possible deaths associated with pregnancy (AbouZahr, 1998), utilisation of these services is still low in rural communities in developing countries mainly due to accessibility reasons. Ghana faces such a problem and rural communities in the Akuapim North District are no exception. The district is characterised by increased rate in unskilled delivery looking at the fact that it rose from $8 \%$ through to $15 \%$ from 2008-2010. Though total antenatal registrants stood at $86.7 \%$ in 2010 , the rate of four antenatal visits and skilled delivery dropped from $89.2 \%$ to $70.1 \%$ and $62.6 \%$ to $58.5 \%$ from 2009 to 2010 respectively (Service Performance Annual Report, 2010). Several researches have described the 
determinants of use of maternal health services but little is found on how individual and area factors determine the use of antenatal and delivery services among rural women in Ghana. Generally, little research has been done in the area of maternal health services use among rural women in Ghana. A study conducted in rural areas only focused on socio-demographic and cultural determinants of maternal-child health service utilization neglecting the effects of area factors (Addai, 2000). Other studies concentrated on the use of health services in general (Buor, 2003). Abor et al., (2011) examined the socio-economic determinants of maternal health service utilization. The use of national data by most researches also limits its applicability to some areas with specific characteristics. This paper seeks to bridge the identified gaps by examining how individual and area factors influence the use of the antenatal and delivery services among women in rural areas in Ghana.

\section{Conceptual Framework}

The behavioural model of health services utilization developed by Anderson (1995) served as the conceptual framework for the study. The use of Maternal Health Services has been assumed to be determined by a sequence of factors namely predisposing, enabling and need. Predisposing factors centre on the idea that some people have a greater tendency to use health services than others. Such factors include age, marital status, educational level and occupation. Enabling factors are seen as supporting resources which may be resources from an individual or those that exist at the community level. Such factors include income, having a health insurance, availability of health facilities and personnel and access to vehicles. Need factor explain the reasons why someone will use the MHS.

\section{Methods}

Akuapim North District is located in the south- eastern part of the Eastern Region of Ghana and is about $58 \mathrm{~km}$ from Accra. The district stretches over an area of 450 square kilometers constituting about 5\% of the entire Eastern Region. The District faces a general lack of adequate staff especially midwives to man some health facilities. Three purposively selected rural communities in the District (Sanfo Ano, Okyerekrom and Kwawdarko) were used for the study. These communities fall under the Okrakwadwo sub-district, one of the eight sub-districts. They are characterized by absence of health facilities, third class roads and transportation problems. Estimated population is between 340 and 650 for each community. An estimated total number of 353 households were recorded for the 3 communities. The communities vary in terms of time taken to get to the nearest town with a range of 14-20 minutes. This time however increases during the rainy season as the road become impassable. Mode of transport to the communities is by road and public transport is by taxi cabs.

This study adopted the quantitative method and employed the descriptive, cross-sectional design. Structured interviews were used in eliciting responses from women (15-49) years who had at least one child aged 3 years or younger from the three selected communities in the District. The questions were both closed and open ended. Data from Annual health reports and service performance reports from the District Health Directorate and Assembly were also used. 


\section{Ml Macrothink}

Journal of Public Administration and Governance ISSN 2161-7104 2013, Vol. 3, No. 2

The target population consisted of all women between the ages of 15-49 who had given birth within the past three years and had at least one child aged 3 years or younger within the communities. A sample size of 319 was determined using EPI INFO STATKALC version 2002 with an expected frequency of $70 \%$ and a worst acceptable frequency of $65 \%$ at the $95 \%$ confidence level from a total population of women in fertile age (WIFA) of 27,687 in the District.

The sampling frame of the study consisted of the total number of households for the three communities. The number of respondents to pick from each community was determined by dividing the number of households for each community over the total number of households for the 3 communities multiplied by the sample size determined. With the given number of respondents for each community, the simple random sampling technique was used to select households in each of the communities. Purposive sampling was then employed to select women within the specified category. In households containing more than one woman, simple random sampling was used to select one. This process was repeated to the last respondent. A total number of 296 women were sampled within a nine week duration.

Respondents were visited in their homes by the research team after pre-testing the instrument and adjustments made accordingly. This exercise was undertaken after permission was granted by the various community heads and the purpose for the research well explained to respondents. Women who fell within the specified category were interviewed from randomly selected households in the three communities. All interviews were conducted in the local language (Twi) which was largely spoken in the area. Each interview lasted within 20 minutes. An interview schedule was used to elicit responses from the respondents with regards to the use of antenatal and delivery services. Questions included the effect of some area variables and demographic information of respondents. Recommendations were also solicited from all respondents.

Four (4) outcome variables (MHS) were considered for the analysis. These are:

Initiation of first ANC: This was defined as whether a woman initiated $1^{\text {st }}$ ANC visits within the first trimester (three months) of the last pregnancy

Total number of ANC visits: This assessed the total number of ANC visits embarked by the women. The WHO recommends four (4) or more ANC visits as optimal number of visits for those with uncomplicated pregnancy.

Place of delivery: This assessed whether delivery took place in a formal health facility (Public / Private hospital, clinic, health centre, maternity home or health post)

Assistance during delivery: This was defined as whether a woman received assistance from a trained medical personnel (Doctor, nurse or midwife).

Several demographic and socio-economic variables (individual factors) and area level variables which served as independent variables were taken to investigate their association with the MHS (see Table 1).

Responses under open ended questions were grouped under similar themes and analysed quantitatively using the chi- square test to establish associations between the variables 
(individual and area factors) and the use of the MHS.

Table 1 Measurement of independent variables used for the study

\begin{tabular}{|c|c|}
\hline VARIABLE & DEFINITION \\
\hline Age at last birth & $\begin{array}{l}\text { Ages of respondents were calculated by subtracting the children's } \\
\text { age from the women's current age. These were further categorized } \\
\text { into three classes: } 15-19,20-24 \text { and } 35-49 \text {. Categorization is based } \\
\text { on high risk groups of pregnancy (teenage mothers and } 35+\text { ). }\end{array}$ \\
\hline Marital status & $\begin{array}{l}\text { This was categorized as Single-1, Married-2, Divorced-3, } \\
\text { Separated-4 and Widowed-5. }\end{array}$ \\
\hline Education & $\begin{array}{l}\text { Highest level of education attained by respondents was divided } \\
\text { into } 6 \text { categories: never attended school-1, Primary-2, JHS-3, } \\
\text { SHS-4, Tertiary- } 5 \text { and other. }\end{array}$ \\
\hline Occupation & $\begin{array}{l}\text { Responses given were grouped as follows: not working-1, } \\
\text { Farmer-2, Trader-3, Hairdresser-4, Seamstress-5 and Caterer- } 6\end{array}$ \\
\hline $\begin{array}{l}\text { Number of } \\
\text { Children }\end{array}$ & $\begin{array}{l}\text { Continuous variable indicating the total number of children a } \\
\text { woman had. }\end{array}$ \\
\hline $\begin{array}{l}\text { Occupation of } \\
\text { husband/partner }\end{array}$ & $\begin{array}{l}\text { This variable was categorised based on responses given as } \\
\text { follows: Not working-1, Farmer- } 2 \text {, Driver- } 3 \text {, Teacher- } 4 \text {, Corn } \\
\text { miller-5, Carpenter-6, Mason-7, Construction labourers- } 8\end{array}$ \\
\hline $\begin{array}{l}\text { Education of } \\
\text { husband/partner }\end{array}$ & $\begin{array}{l}\text { Similar to the educational level attained by the women, this was } \\
\text { categorized into } 6 \text { groups: never attended school, Primary, JHS, } \\
\text { SHS, Tertiary and Other. }\end{array}$ \\
\hline $\begin{array}{l}\text { Average monthly } \\
\text { income }\end{array}$ & $\begin{array}{l}\text { Describing how much was earned at the end of the month by } \\
\text { respondents. This variable was categorized as 1-50cedis, } \\
51-100 \text { cedis and } 150 \text { cedis and above. }\end{array}$ \\
\hline $\begin{array}{l}\text { Health Insurance } \\
\text { Status }\end{array}$ & $\begin{array}{l}\text { A dichotomous variable (Yes or No) indicating the status of the } \\
\text { respondent. Yes was coded as } 1 \text { and } 2 \text { for No. }\end{array}$ \\
\hline Nature of road & $\begin{array}{l}\text { Based on the perception of the women, this variable was rated as } \\
\text { Very Poor-1, Poor-2, Fair-3, Good- } 4 \text { and Very good- } 5 \text {. }\end{array}$ \\
\hline $\begin{array}{l}\text { Time taken to get } \\
\text { to a health facility }\end{array}$ & $\begin{array}{l}\text { From the perspective of the women, this variable was rated as } \\
\text { Very long-1, Long- } 2 \text {, Moderate- } 3 \text {, Short- } 4 \text { and Very Short- } 5\end{array}$ \\
\hline Accessibility of & These two variables were given the same ratings as Very poor-1, \\
\hline
\end{tabular}




\begin{tabular}{|l|l|}
\hline $\begin{array}{l}\text { public and } \\
\text { emergency } \\
\text { vehicles }\end{array}$ & Poor-2, Moderate-3, Good-4 and Very good-5. \\
\hline $\begin{array}{l}\text { Cost of } \\
\text { transportation }\end{array}$ & $\begin{array}{l}\text { This variable described the perception on the cost involved in } \\
\text { transportation to a health facility. Ratings were Very high-1, } \\
\text { High-2, Moderate-3, Low-4 and Very low-5. }\end{array}$ \\
\hline $\begin{array}{l}\text { Overall access to a } \\
\text { health facility }\end{array}$ & $\begin{array}{l}\text { This variable described the general view of respondents with } \\
\text { regards to accessing a health facility. This was rated as Very } \\
\text { difficult-1, Difficult-2, Moderate-3, Easy-4 and Very easy-5. }\end{array}$ \\
\hline
\end{tabular}

\section{Results}

A total number of $296(92.8 \%)$ respondents were interviewed out of the 319 required sample size due to difficulty in accessing the 23 respondents. Many women were sampled from Sanfo Ano (46.6\%) than the other communities in the District. Half of the women were in ages between 20 and 34 years whereas almost an equal proportion of the women were divided between the teenage women and those in their mid thirties and above. About two thirds of the women were married and a quarter $(25.7 \%)$ was single. Seventy - seven percent of the married lived with their husbands; and 108 (36.5\%) women lived with parents or relatives. The majority of the women who lived with their parents or relatives were mothers between the ages 15 and 34 years - who were predominantly single. Two - thirds of the women had between one and three children; a third had more than three children and the highest number of children born among the respondents ( 2 women specifically) was 7 . A quarter of the women were not working. Slightly more than $10 \%$ practiced a vocational skill (hairdressing and sowing) and about $20 \%$ indulged in some form of trading and selling food. Though these varied occupations gave them some income, only $65.5 \%$ reported their income. Of the proportion of women who reported their income, more than half (61.9\%) earned only up to $\mathrm{GH} \phi 50.00$ per month while only $4 \%$ earned above $\mathrm{GH} \phi 100$. The rest earned between $\mathrm{GH} \phi 51$ - 100. About a quarter of the women (23.6\%) had no formal education. Only $0.3 \%$ had some senior high school education. The levels of education of the husbands seem to be generally higher than that of the married women. For example whereas about two - thirds $(69 \%)$ of the men have had at most junior high school education, the proportion was $98.5 \%$ among women; implying that almost none of the women had academic training beyond junior high. About $2.1 \%$ of the husbands were unemployed and the majority were either farmers $(54.2 \%)$ or drivers $(19.7 \%)$. Furthermore, only $57 \%$ of the rural women were on the national Health Insurance Scheme.

\subsection{Use of antenatal care and delivery services}

Results indicate that majority (97\%) of the women underwent antenatal care during pregnancy. The modal number of visits undertaken by the women was 4 with about a fifth of the women visiting more than 6 times. Only $2.8 \%$ of women have attended antenatal care 
once. About $47.9 \%$ made visits to a health facility for antenatal treatment during the first trimester (1 -3 months) of the pregnancy. A few women however attended antenatal care only in the last $7-9$ months. However, the women visited the hospital for various reasons. Notable among the reasons were illness $(50 \%)$. Some went for antenatal on the advice of a health professional, husband or mother. Others attended for the purposes of 'medical check up' or for drugs and medication. About $2.1 \%$ attended because they saw others do so. The few women who refused antenatal treatment did so because of financial constraints $(25 \%)$, absence of sickness (50\%), or for no particular reason (25\%). Less than half of the women (39.9\%) delivered in a health facility while about $60 \%$ delivered at home. With regards to the women who delivered at home, only two got the assistance of a midwife or nurse; a great number of them were assisted by a neighbour (43.8\%) and a Traditional Birth Attendant $(40.4 \%)$. Some $(14.6 \%)$ delivered all by themselves.

\subsection{Description of the use of maternal health services in the communities}

A description of the use of the maternal health services was done in relation to the requirements by WHO $(1994 ; 2004)$. It is considered medically satisfactory when:

- Women receive antenatal care during their first trimester

- Women undertake four or more antenatal visits before delivery

- Women are attended to at delivery by trained medical personnel

- Delivered in a health facility.

Information on the proportion of women who satisfy the maternal health outcomes are provided in Table 2

Table 2 Proportion of cases (women) who satisfy the maternal health outcomes

\begin{tabular}{|l|l|}
\hline Maternal Health Outcomes & Proportion \\
\hline Antenatal care in first trimester & $138(46.6 \%)$ \\
\hline Antenatal visits of four (4) or more & $230(77.7 \%)$ \\
\hline Attendance by medical trained personnel & $120(40.5 \%)$ \\
\hline Delivery in a health institution & $118(39.9 \%)$ \\
\hline
\end{tabular}

Results indicate that except for the total number of satisfactory antenatal visits, less than half of the women could be said to have satisfied the maternal health outcomes - during pregnancy and delivery. Many of the women (77.7\%) had visited the hospital at least four times during their period of pregnancy. Many of the women (98.6\%) used the public health institutions as opposed to private health institutions. 


\section{Macrothink}

Respondents who used health facilities for delivery in general were motivated by the fact that they were too young, it was a free delivery service, or it was their first time delivery. The predominant factors emanated from complications with pregnancy or delivery $(46.6 \%)$ and the need to practice safe delivery (29.7\%). However, respondents who did not give birth in a health facility mentioned financial constraints (39.3\%) and transportation challenges $(23.6 \%)$ as the main reasons. Some respondents $(15.7 \%)$ just chose not to attend a health centre for delivery. However, other reasons advanced by the women were impromptu deliveries and bad perception about nurses, but some (6.7\%) simply preferred the traditional birth attendant. It took many women $(53.2 \%)$ who visited a health facility 30 minutes and it took a further third (33.9\%) of women an hour to get to a health centre.

\subsection{The influence of area and individual factors on the use of the Maternal Health Services}

Chi-square test results for the relationship between the specified area factors and antenatal care services are shown in Table 3.

Table 3 Relationship between Area factors and ANC services

\begin{tabular}{|c|c|c|c|c|c|}
\hline & $\begin{array}{c}\text { ANC }\left(1^{\text {st }} \text { trim }\right) \\
\chi^{2}\end{array}$ & p-value & $\begin{array}{c}>4 \text { ANC visits } \\
\chi^{2}\end{array}$ & p-value & df \\
\hline Nature of road & 25.722 & .000 & 9.965 & .019 & 3 \\
\hline Access to vehicles & 8.095 & .088 & 2.243 & .691 & 4 \\
\hline $\begin{array}{l}\text { Access to } \\
\text { emergency vehicles }\end{array}$ & 3.656 & .161 & 1.466 & .480 & 2 \\
\hline $\begin{array}{l}\text { Time taken to } \\
\text { health facility }\end{array}$ & 23.187 & .000 & 9.784 & .044 & 4 \\
\hline $\begin{array}{l}\text { Cost of } \\
\text { transportation }\end{array}$ & 11.999 & .017 & 9.978 & .041 & 4 \\
\hline $\begin{array}{l}\text { General access to } \\
\text { health facility }\end{array}$ & 15.824 & .003 & 3.587 & .465 & 4 \\
\hline
\end{tabular}

$\mathrm{p}<.05=$ significant $\quad \mathrm{p}>.05=$ non significant

The groups of women defined by antenatal care during the first trimester of their pregnancy had different views on the quality of roads that linked their homes to the health facility $(\mathrm{p}<.01)$. Larger proportions of women who did not undertake antenatal during the first trimester were more associated with the opinion that the connecting roads were bad. The 
groups also showed significant difference in opinion on time taken to get to the health facility $(\mathrm{p}<.01)$, cost of transportation $(\mathrm{P}<.05)$ and general access to health $(\mathrm{p}<.01)$.

In explaining further, comparatively many women who did not go for antenatal during their first trimester considered the time spent on the journey to the health facility as being too long $(\mathrm{p}=0.000)$. They also thought the cost of transportation was too high $(\mathrm{p}<.05)$ and general access to health facility was difficult $(\mathrm{p}<.05)$. Similarly, comparatively more women who could not visit the health facility for at most the fourth time, thought the nature of the roads were poor $(\mathrm{p}<.05)$ and that it took longer time to get to the hospital $(\mathrm{p}<.05)$.

Table 4 Relationship between Area factors and Delivery services

\begin{tabular}{|c|c|c|c|c|c|}
\hline & $\begin{array}{l}\text { Skilled delivery } \\
\qquad \chi^{2}\end{array}$ & p-value & $\begin{array}{l}\text { Institutional } \\
\text { Delivery } \chi^{2}\end{array}$ & p-value & $\mathrm{df}$ \\
\hline Nature of road & 5.831 & .120 & 5.619 & .132 & 3 \\
\hline Access to vehicles & 19.915 & .001 & 18.437 & .001 & 4 \\
\hline $\begin{array}{l}\text { Access to } \\
\text { emergency vehicles }\end{array}$ & 3.722 & .156 & 3.548 & .170 & 2 \\
\hline $\begin{array}{l}\text { Time taken to } \\
\text { health facility }\end{array}$ & 39.229 & .000 & 41.148 & .000 & 4 \\
\hline $\begin{array}{l}\text { Cost of } \\
\text { transportation }\end{array}$ & 33.755 & .000 & 36.286 & .000 & 4 \\
\hline $\begin{array}{l}\text { General access to } \\
\text { health facility }\end{array}$ & 13.338 & .010 & 14.810 & .005 & 4 \\
\hline
\end{tabular}

$\mathrm{p}<.05=$ significant $\quad \mathrm{p}>.05=$ non significant

Table 4 illustrates that views on nature of roads and access to emergency vehicles did not differ much among those who delivered in the hospital and those who did not ( $p>.05)$ and also those attended to by medical personnel and those not ( $p>.05$ ). All the other area factors proved significant. Additionally, women who delivered at home and or could not see a health personnel, seem to be more associated and shared uncomplimentary opinion on access to vehicles, journeying time, transportation costs and general access to a health facility. These factors could thus be seen as militating factors to the incidence of delivering at the hospital and seeking the assistance of a trained health personnel. 


\section{Macrothink}

Age, marital status, occupation of respondent and family size seem to play a significant role in the use of both ANC within the first trimester and four (4) or more ANC visits ( $\mathrm{p}<.01)$ (see Table 5 below).

Table 5

Relationship between Individual factors and ANC services

\begin{tabular}{|c|c|c|c|c|c|}
\hline & $\begin{array}{r}\left.\text { ANC ( } 1^{\text {st }} \text { trim }\right) \\
\chi^{2}\end{array}$ & p-value & $\begin{array}{c}>4 \text { ANC visits } \\
\chi^{2}\end{array}$ & p-value & $\mathrm{df}$ \\
\hline Age & 89.118 & .000 & 36.823 & .000 & 2 \\
\hline Marital Status & 31.891 & .000 & 19.741 & .001 & 4 \\
\hline Education level & 6.317 & .177 & 5.616 & .230 & 4 \\
\hline $\begin{array}{l}\text { Family size (No. of } \\
\text { children) }\end{array}$ & 107.33 & .000 & 61.069 & .000 & 6 \\
\hline $\begin{array}{l}\text { *Education level of } \\
\text { partner }\end{array}$ & 35.785 & .000 & 4.478 & .483 & 5 \\
\hline $\begin{array}{l}\text { Occupation } \quad \text { of } \\
\text { respondent }\end{array}$ & 44.947 & .000 & 21.011 & .001 & 5 \\
\hline $\begin{array}{l}\text { *Occupation of } \\
\text { respondent's partner }\end{array}$ & 16.857 & .018 & 9.463 & .221 & 7 \\
\hline $\begin{array}{l}\text { Health Insurance } \\
\text { status }\end{array}$ & .031 & .861 & .001 & .979 & 1 \\
\hline
\end{tabular}

$\mathrm{p}<.05=$ significant $\quad \mathrm{p}>.05=$ non significant $\quad *$ considered only the married

However, the educational level and health insurance status of respondents did not have a significant association with the outcomes ( $>$ >.05). Women who were relatively younger tended to attend antenatal care more and in the first trimester; the same can be said about those who are single or have fewer children (smaller family size) or not working.

Table 6 indicates that unlike the ANC services, the educational level and occupation of partner and health insurance status had a significant association between delivery in a health facility and assistance at delivery by trained medical personnel $(\mathrm{p}<.05)$. In addition, age, marital status and family size played a significant role in the use of the delivery service $(\mathrm{p}<.05)$. Delivery at the health facility and being attended to by health personnel were found to be more associated with the young, the single, smaller family size, higher level of 
education, occupation of the husband and possession of national health insurance. It was found that women who could not achieve these maternal outcomes were farmers or had husbands who were mostly farmers.

Table 6 Relationship between Individual factors and Delivery services

\begin{tabular}{|c|c|c|c|c|c|}
\hline & $\begin{array}{l}\text { Skilled } \\
\text { delivery } \chi^{2}\end{array}$ & p-value & $\begin{array}{l}\text { Institutional } \\
\text { Delivery } \chi^{2}\end{array}$ & p-value & $\mathrm{df}$ \\
\hline Age & 27.807 & .000 & 29.821 & .000 & 2 \\
\hline Marital Status & 15.073 & .005 & 16.107 & .003 & 4 \\
\hline Education level & 5.656 & .226 & 6.913 & .141 & 5 \\
\hline $\begin{array}{l}\text { Family size (No. of } \\
\text { children) }\end{array}$ & 25.709 & .000 & 28.983 & .000 & 6 \\
\hline $\begin{array}{l}\text { *Education level of } \\
\text { partner }\end{array}$ & 21.316 & .001 & 22.132 & .000 & 5 \\
\hline $\begin{array}{l}\text { Occupation } \quad \text { of } \\
\text { respondent }\end{array}$ & 8.958 & .111 & 10.393 & .065 & 5 \\
\hline $\begin{array}{l}\text { *Occupation of } \\
\text { respondent's partner }\end{array}$ & 22.834 & .002 & 24.494 & .001 & 7 \\
\hline $\begin{array}{l}\text { Health Insurance } \\
\text { status }\end{array}$ & 16.726 & .000 & 15.184 & .000 & 1 \\
\hline
\end{tabular}

An array of suggestions was given by the respondents with regards to what could be done to improve the maternal health outcomes. Improving on the transportation system was one of the most important measures to them. Others rooted for the training of traditional birth attendants.

\section{Discussion}

In describing the use of antenatal care and delivery services in the area, it was found that antenatal attendance was higher than delivery services. High levels of antenatal care did not commensurate with utilisation of delivery services as espoused by Abou-Zahr and Wardlaw (2003) and Gage (2007). This was evident from findings of the study where general ANC attendance was $97 \%$ as against $39.9 \%$ health institution deliveries. Ninety-nine percent (99\%) 
of antenatal care were sought from public health institutions and this is contrary to the findings of Wong et al. (1987) in Philippines where $45 \%$ of rural women sought antenatal care from traditional practitioners. This could be as a result of the free maternal delivery policy which has increased the utilisation of health care in most public health institutions.

The first initiation of antenatal care (WHO 1994; 2004) saw less than half of the respondents $(46.6 \%)^{1}$ meeting this standard. Four or more antenatal visits was $77 \%$ and this was higher than the national percentage which is 72 (GDHS, 2008). The use of skilled personnel at delivery which was highly associated with the use of health facility for delivery was $40.5 \%$. Again, delivery in a health facility was $39.9 \%$ and this was lower than the $41.7 \%$ (GDHS, 2008) rate for delivery in health facilities for rural areas in Ghana. The reason for the difference could be attributable to differences in the characteristics of samples used. Total assistance from unskilled personnel was $59.5 \%$. Out of this, TBAs constituted $40.4 \%$ and this almost confirms the $41.3 \%$ use of TBAs in rural areas in Ghana.

Generally, if optimum results are to be achieved with the utilisation of maternal services, then there should be absolute and proper use of them. Not complying with all the standards could mar the desired results expected. This is reflected in Ghana where there is $95 \%$ antenatal attendance but maternal mortality rate is still high. Attending antenatal at the early stages of pregnancy, embarking on regular checkups and getting the assistance of a trained medical personnel at delivery could assist in the early identification and treatment of complications and help in the reduction of maternal mortality (WHO, 1994; 2004).

Similarly, the issue of sickness was the major reason (50\%) given by respondents for attending antenatal visit. It can therefore be inferred that sickness in pregnancy is the most motivating factor for initiation of antenatal care in the area and this upholds the perceived need factor in the model used for the study. Pregnant women saw illness during pregnancy as a justification to see a health professional but a good understanding of the relevance of the services to both mother and child should be laid.

Findings on the influence of individual and area factors were largely supported by the model used for the study. Results from the analyses indicated that the age of the respondents highly influenced the use of all the maternal health outcomes ${ }^{2}$. Younger mothers were predisposed to using antenatal care early and more, delivering in health facilities and seeking the assistance of trained medical personnel at delivery than older women. This contradicts findings of Paul and Rumsey (2002) that type of assistance utilised during delivery does not differ significantly with the age of the mother. This could be that during the time the other research was conducted there were no other options available to mothers than to call on a particular attendant for assistance during delivery.

Again, findings did not support that women over 35years are less likely to use ANC but more likely to utilise delivery care (Sharma et al., 2007). It was found that both ANC and delivery services were less utilised by older women probably because they have had more birth experiences without complications. Having a complication history or complication with

\footnotetext{
Table 1

2 See Tables 4 \&5
} 
current pregnancy served the major need to seeking delivery services. Marital status was also found to be associated with all the maternal health outcomes. Single women were also predisposed to use the MHS more than married women. More than half (52.6\%) of the single mothers were teenagers and about $54.3 \%$ were living with their parents/relatives. This may have influenced the use of the MHS as teenagers may lack the independence and power to make decisions and may be compelled to accept decisions made on their behalf. This could explain for the situation where some respondents claimed they used the services based on the advice given to them that they were young by their mothers and others.

Similarly, smaller family size was highly associated with all the maternal health outcomes. Thus, a woman with few children was seen as more likely to use the MHS as compared to those with larger family size. This finding is consistent with another study (Elo, 1992). It also confirms that of Wong et al. (1987) that first births and births of younger women were more likely to be delivered in a health facility under medical supervision. Further explanations could be that because pregnancies were mostly respondents' first time, they were more cautious because of the perceived risk associated with first pregnancies. The women, when they feel they are sick most of the time just report to the clinic even if their time for check up is not due.

Interestingly, findings from this study indicated that the level of education of the respondents were not significantly associated with all the maternal health outcomes ( $\mathrm{p}$ values >0.05). This is contrary to other research findings (Elo, 1992; Raghupathy, 1996; Chakraborty et al., 2003). This finding could be due to the fact that most of the respondents to an extent knew about the MHS irrespective of their educational background. It therefore suggests that Knowledge on MHS is not tied to formal education. Thus, people could be educated through informal means such as the radio among others. Arguing further, though several researches have shown a positive influence of education on the utilization of MHS, contrary results from this study could be due to how education was measured. The distinction between education and non education was a respondent's attempt to go to school irrespective of the level and never being to school. It could therefore be hasty to discount the relevance of education in the utilisation of MHS.

However, the educational level of respondents' husbands was associated with antenatal visit within the first trimester and four or more visits. Interestingly, respondents who utilised the services had husbands with lower levels of education as compared to those who did not use them. This confirms claims in this study that information and use of antenatal care is not limited to the level of education of both women and husbands. Care during pregnancy is now free and community health officers are now doing rigorous education to create awareness on MHS utilisation in rural areas. The occupations of respondents and their husbands were also associated with some of the maternal health outcomes. In both cases, being a farmer or having a farmer as a husband increased the likelihood of initiating antenatal visit first within three months of pregnancy. Women who also utilized delivery services also had husbands who were farmers. Findings did not support a study in rural Bangladesh where Paul and Rumsey (2002) reported that fathers employed in non-farm occupations chose trained personnel for delivery more frequently than those who were farmers. Differences in results 
however could be due to time factor and context of the studies. Explaining further, results could be due to the fact that farming is the dominant profession in the area and most of the respondents and their husbands were farmers.

Moreover, having a health insurance increased the likelihood of health facility delivery as compared to not having one. This served as an enabling resource for the individual women to utilize health services as seen from Andersen's model. It may also have reduced respondents' financial burden as most of the respondents who delivered at home cited financial problem as the major reason for not going to a health facility.

Shifting attention to the area level variables, all the respondents were of the view that all the selected variables did not support the maternal health outcomes. This also indicates that the resources that were supposed to exist at the community level to boost MHS utilisation were non-existent. Negative opinions were shared on all the factors as facilitating access to a health facility. The nature of road was associated with the use of antenatal care (ANC) within the first trimester and four or more visits. Respondents who did not attend ANC within the first trimester were of the view that the connecting road was bad ( $p$ value $=0.000$ ). This finding is supported by Dana et al., (2003) that poor road conditions can prevent the use of health care services. Findings can also be explained that most women in their early stages of pregnancy are very cautious to prevent any activity that could cause a possible miscarriage. Access to vehicles tended to be associated with delivery care services ( $p>0.01)$. Respondents who delivered at home shared negative opinion on access to vehicles. This is consistent with reasons given by $23.6 \%$ of the respondents who delivered at home as related to transportation problems.

Similarly, women who could not receive assistance from a trained medical personnel during delivery or delivered in a health facility shared opinion that the cost of transportation was high. In the same vein, respondents who did not visit the health facility for care during the first trimester and attended less than four visits shared that transportation cost was high. Also, time taken to get to a health facility was associated with all the maternal health outcomes. More than half of the respondents spent 30 minutes on the average to get to a health facility. It was also found that the nearest health facilities only rendered antenatal care and women had to go to Okrakwadwo clinic to deliver. Time taken to access the various health facilities according to the respondents goes up to an hour or more during the rainy season as getting a car and plying the road becomes difficult. Investigating into distance issues, time taken to cover a distance may vary depending on the conditions available. If one gets a car on time and on a good road, time used will be comparatively shorter for a long distance as compared to a shorter one with difficulties in getting a car coupled with poor condition of road.

\subsection{Strengths and Limitation}

This study provides information about the utilisation of antenatal and delivery services in rural areas in Ghana. It brings out how individual and area level factors affect the utilisation of these maternal health services. This is instrumental in informing policymakers on the resource needs in rural areas and advancing appropriate measures for intervention. The study however is limited in drawing conclusions on the use of other maternal health services such 
as post natal care and family planning. Others studies are needed to explore these. The quantitative nature of this study makes it silent on the in-depth explanations given on the use of the maternal health services. An examination of institutional factors and content and quality of antenatal and delivery care could expand views on the use of these services by rural women. Other researches can focus on resource challenges in operationalising the free maternal delivery in public health centres in rural areas. Nevertheless, the validity of the study's results is unlikely to be affected by these issues.

\section{Conclusion and Recommendations}

Women in rural areas are seen as vulnerable due to certain peculiar issues related to where they find themselves as well as other individual challenges. The use of the MHS according to the present study was inadequate. On a broader perspective, to begin with, drivers in the health sector need to adopt a multi-sectoral approach if meaningful results are to be achieved in improving utilisation of MHS in rural areas and maternal health in general. Consultations with the Ministries of Local Government and Rural Development, Road and Transport, Education, Communication and information should be made on issues relating to rural health in general and maternal health in particular. As evident in this study, the area level factors had a great toll on almost all the maternal health outcomes. The respective ministries involved as well as other NGOs could come to the aid of the rural folks in reconstructing the roads that link the communities to other areas especially health centres.

It was also found that some of the respondents attended antenatal visit on the information that a pregnant woman is expected to attend without taking into account the timing of the visit. To those women, they would consider themselves as having gone for ANC even if the visit was in the ninth month of pregnancy. Antenatal is expected to serve its intended purpose and must not be seen as a ritual that a pregnant woman can perform anytime she feels like regardless of the timing. Focus could especially be on older women who due to several experiences from pregnancies tend to discount the relevance of the MHS. It should be noted to them that by virtue of their age they fall within those prone to more complications. Again, efforts should be made toward empowering women through formal education to equip them with the necessary skills to earn and control income. Findings indicated that about a quarter of the women had no formal education and were not working. This would help increase the autonomy of women in seeking to issues regarding their own health as many respondents attributed the non use of the services to financial reasons. Women could also be trained to take up other vocations to supplement their incomes as the general levels of incomes disclosed were low.

Furthermore, enough trained medical personnel should be posted to the District as seen from the profile that some of the CHPS compounds were limited to providing antenatal care only because of the absence of midwives. Moreover, research findings indicates that the strict adherence to the WHO standard of getting assistance from a skilled attendant would not be feasible in many rural settings due to resource constraints and other traditional beliefs. Traditional Birth Attendants could be incorporated to assist women in emergency situations due to access problems by going through several training programmes and workshops to equip them with the necessary skills. This was also evident from some of the 
recommendations made by the respondents.

Again, matters relating to the operation of the NHIS should be made clear to subscribers as many complained of additional charges that were requested even though it was captioned "free". This study has established that the use of the MHS is not adequate in the area. The scope of the study did not cover other MHS such as post natal care and family planning. Other researches could also focus on these MHS to establish and understand their determinants of use. Findings from the current study though not exhaustive suggest some institutional factors as influencing the use of the MHS. Other researches can focus on resource challenges in operationalising the free maternal delivery in public health centres in rural areas as well as the content and quality of antenatal care.

\section{Acknowledgement}

The authors wish to acknowledge the District Director of Health and staff of the Health Directorate in the Akuapim North District of Ghana for their invaluable time and information. We also appreciate the immense support and cooperation of the community heads and people of Sanfo Ano, Okyerekrom and Kwawdarko during this study. We also appreciate all research assistants who helped in the data collection phase especially Mr. Steve Annan. We also thank the University of Ghana Business School, Legon for its support during the course of this study.

\section{References}

Abor, P. A., Abeka-Nkrumah, G., Sakyi, K., Adjasi, C.K.D and Abor, J. (2011). The Socio-economic Determinants of Maternal health care Utilisation in Ghana. International Journal of Social Economics, 38, 7

Abou-Zahr, C. L., and Wardlaw, T. M. (2003). Antenatal care in developing countries: Promises, achievements and missed opportunities: An analysis of trends, levels and differentials, 1990- 2001. Geneva: WHO and UNICEF

AbouZahr, C. (1998). Maternal and prenatal health. In C. J. L. Murray, and A. D. Lopez (Eds.), Health dimensions of sex and reproduction. Global Burden of Disease and Injury Series, 3, 111-164

Addai, I. (2000). Determinants of use of maternal-child health services in rural Ghana. Journal of Biosocial science, 32(1): 1-15.

Andersen, R. M. (1995). Revisiting the behavioral model and access to medical care: Does it matter? Journal of Health and Social Behaviour, 36, 1-10.

Buor, D. (2003). Analysing the primacy of distance in the utilization of health services in the Ahafo- Ano South District, Ghana. International Journal of Health Planning and Management Policy, 69,375-388.

Chakraborty, N., Islam, M. A, Chowdhury, R. I., Bari, W and Akhter, H. H. (2003). Determinants of use of maternal health services in rural Bangladesh. Health Promotional International, 18 (4), 327.

Dana, A., Noreen, G. and German, R. (2003). Utilisation of care during pregnancy in rural 
Guantemala: does obstetrical need matter? Social Science \& Medicine, 57, 2447-2463

Elo, I.T. (1992). Utilization of maternal health care services in Peru: the role of women's education. Health Transition Review, 2 (1), 1-20.

Gage, A. J. (2007). Barriers to the utilization of maternal health care in rural Mali. Social Science \& Medicine, 65(8), 1666-1682.

Ghana Demographic and Health Survey (2008) Report

Magadi, M. A., Agwanda, A. O and Obare, F. O. (2007). A comparative analysis of the study of use of maternal health services between teenagers and older mothers in sub-Saharan Africa: Evidence from Demographic and Health survey. Social Science and Medicine, 64,1311-1325

Magadi, M. A., Madise, N. J. and Rodrigues, R. N. (2000). Frequency and timing of antenatal care in Kenya: Explaining the variations between women of different communities. Social Science \& Medicine, 51,551-561.

Paul, B. K. and Rumsey, D. J. (2002). Utilization of health facilities and trained birth attendants for childbirth in rural Bangladesh: an empirical study. Social Science and Medicine, 54,1755-1765.

Raghupathy, S. (1996). Education and the use of maternal health care in Thailand. Social Science Medicine, 43 (4), 459-471.

Rahaman, M. M., Aziz, K. M., Munshi, M. H., Patwari, Y. and Rahman, M. (1982). A diarrhea clinic in rural Bangladesh: influence of distance, age and sex on attendance and diarrheal mortality. American Journal of Public Health, 72, 1124-1128.

Service Performance Annual Report (2010). Akuapim North District Health Directorate.

Shariff, A. and Singh, G (2002). Determinants of maternal health care utilisation in India: Evidence from a recent household survey. NCAER, Working Paper Series No. 85. New Delhi: National Council of Applied Economic Research.

Sharma, S. K., Sawangdee, Y. and Sirirassamee, B. (2007). Access to health: women's status and utilization of maternal health services in Nepal. Journal of Biosocial Science, 39, 671-692.

Thaddeus, S. and Maine, D. (1994). Too far to walk: maternal mortality in context. Social Science and Medicine, 38 (8), 1091-1110.

United Nations Population Fund (UNFPA) (2004). State of the World's Population 2004: Maternal Health, New York.

United Nations (2005). The Millennium Development Goals Report 2005. New York: United Nations.

World Health Organisation (2004). The Critical Role of the Skilled Attendant: A Joint Statement by WHO, J.C.M and FIGO. Geneva.

WHO (1996). Mother-Baby-Package: Implementing safe motherhood in countries. Maternal Health and Safe Motherhood Programme, Geneva. 


\section{Macrothink}

Journal of Public Administration and Governance ISSN 2161-7104 2013, Vol. 3, No. 2

WHO (1994). Antenatal care Report of a Technical working Group. World Health organization: Geneva.

Wong, E. L., Popkin, B. M., Guilkey, D. K. and Akin, J. S. (1987). Accessibility, quality of care and prenatal use in the Philippines. Social Science \& Medicine, 24(11), 927-944.

\section{Appendix 1}

The Researcher is a student of the University of Ghana Business School, doing an MPHIL in Health Services Management. She is researching in the area of Factors Influencing the Utilization of Maternal Health Services: The Perspective of Rural Women in Ghana in partial fulfillment of the award of a Masters degree in the above named course. This questionnaire is for academic purpose only and respondents are assured of utmost confidentiality. Thank you for your co-operation.

\begin{tabular}{|c|c|c|}
\hline ITEM & $\begin{array}{l}\text { SECTION A: RESPONDENT'S } \\
\text { DEMOGRAPHIC AND SOCIO-ECONOMIC } \\
\text { CHARACTERISTICS }\end{array}$ & RESPONSE \\
\hline 1. & Community of residence & $\begin{array}{l}\text { Sanfo Ano............... } 1 \\
\text { Okyerekrom.............. } 2 \\
\text { Kwawdarko................. }\end{array}$ \\
\hline 2. & How old are you? & (n. \\
\hline 3. & Marital Status & 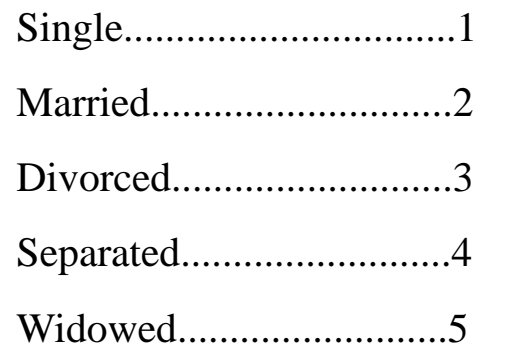 \\
\hline $3 b$. & Who do you live with? & 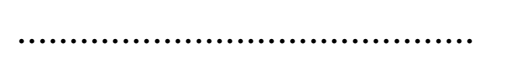 \\
\hline 4. & Religion & $\begin{array}{l}\text { Islam } \ldots \ldots \ldots \ldots \ldots \ldots \ldots \\
\text { Christianity................ } 2 \\
\text { Traditional................. } 3 \\
\text { Other........................ } 99\end{array}$ \\
\hline 5. & Level of Education & $\begin{array}{l}\text { Never attended School.......1 } \\
\text { Primary.....................2 } \\
\text { JSS/JHS..................... }\end{array}$ \\
\hline
\end{tabular}




\begin{tabular}{|c|c|c|}
\hline & & 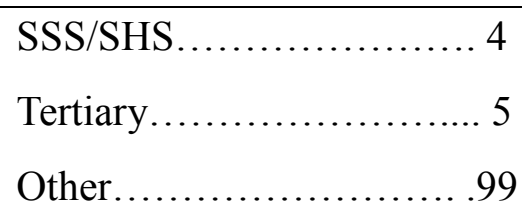 \\
\hline 6. & What is your occupation? & \\
\hline 7. & How many children do you have? & \\
\hline 8. & How old is your last born? & \\
\hline 9. & Husband/ Partner's level of Education & 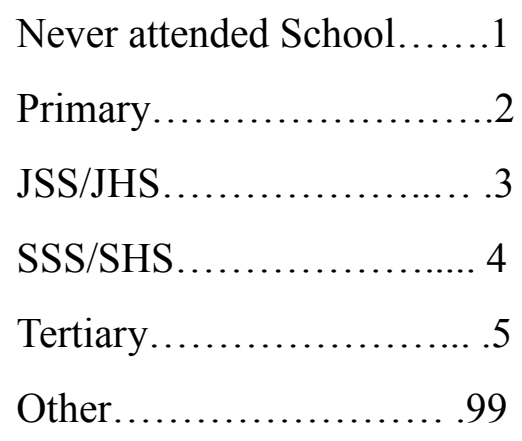 \\
\hline 10. & $\begin{array}{l}\text { What is the occupation of your husband } \\
\text { /partner? }\end{array}$ & ....... \\
\hline 11. & $\begin{array}{l}\text { About how much is your average income per } \\
\text { month in monetary terms? }\end{array}$ & . \\
\hline & $\begin{array}{l}\text { SECTION C: GENERAL STATE OF } \\
\text { ANTENATAL CARE (ANC) ATTENDANCE }\end{array}$ & \\
\hline 13. & $\begin{array}{l}\text { Did you attend antenatal visits when you were } \\
\text { pregnant? }\end{array}$ & $\begin{array}{l}\text { Yes...................... } \\
\text { No...................... } 2 \\
\text { If No } \rightarrow \text { go to question } 19\end{array}$ \\
\hline 14. & Where did you attend your antenatal visits? & \\
\hline 15 . & $\begin{array}{l}\text { Approximately how many minutes /hours did } \\
\text { it take you to get to the place? }\end{array}$ & \\
\hline 16. & $\begin{array}{l}\text { How old was your pregnancy when you started } \\
\text { antenatal visits? }\end{array}$ & $\begin{array}{l}1-3 \text { months } \ldots \ldots \ldots \ldots \ldots \ldots \ldots 1 \\
4-6 \text { months.................... } \\
\text { 7-9months.................. } \\
\text { Don't know................ } 4\end{array}$ \\
\hline
\end{tabular}




\begin{tabular}{|c|c|c|}
\hline 17. & $\begin{array}{l}\text { What made you decide to attend antenatal } \\
\text { visit? (Multiple responses are allowed) }\end{array}$ & $\begin{array}{l}\text { I was sick.................1 } \\
\text { Saw other pregnant women } \\
\text { attending................ } \\
2 \\
\text { Husband told me...........3 } \\
\text { Other, specify.............99 }\end{array}$ \\
\hline 18. & $\begin{array}{l}\text { How many antenatal visits did you attend } \\
\text { before you gave birth? }\end{array}$ & \\
\hline \multirow[t]{2}{*}{19.} & $\begin{array}{l}\text { What prevented you from attending antenatal } \\
\text { visits? }\end{array}$ & \\
\hline & $\begin{array}{l}\text { SECTION D: PLACE OF DELIVERY AND } \\
\text { ASSISTANCE DURING BIRTH }\end{array}$ & \\
\hline 20. & Where did you deliver your last baby? & $\begin{array}{l}\text { Health Facility............ } \\
\text { Home.................. } \\
\text { If (home) } \rightarrow \text { go to question } \\
22 .\end{array}$ \\
\hline 21. & $\begin{array}{l}\text { What made you decide to deliver in a health } \\
\text { facility? }\end{array}$ & \\
\hline \multirow[t]{2}{*}{22.} & $\begin{array}{l}\text { What made you decide to deliver at home? } \\
\text { (Multiple responses are allowed) }\end{array}$ & \\
\hline & SECTION E: COMMUNITY LEVEL INPUTS & \\
\hline 24. & Nature of road to a health facility. & 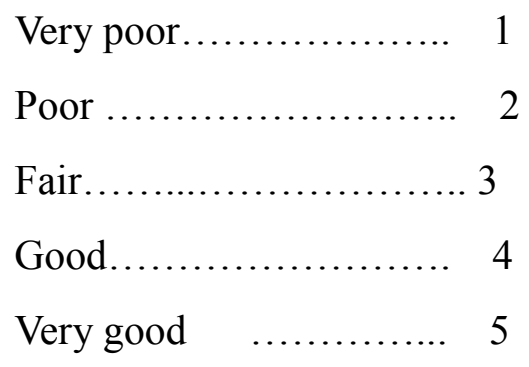 \\
\hline 25. & $\begin{array}{l}\text { Accessibility of public vehicles to a health } \\
\text { facility. }\end{array}$ & $\begin{array}{ll}\text { Very poor } \ldots \ldots \ldots \ldots \ldots \ldots & 1 \\
\text { Poor } \ldots \ldots \ldots \ldots \ldots \ldots \ldots \ldots & 2 \\
\text { Moderate } \ldots \ldots \ldots \ldots \ldots \ldots \ldots & 3 \\
\text { Good } \ldots \ldots \ldots \ldots \ldots \ldots \ldots \ldots & 4\end{array}$ \\
\hline
\end{tabular}




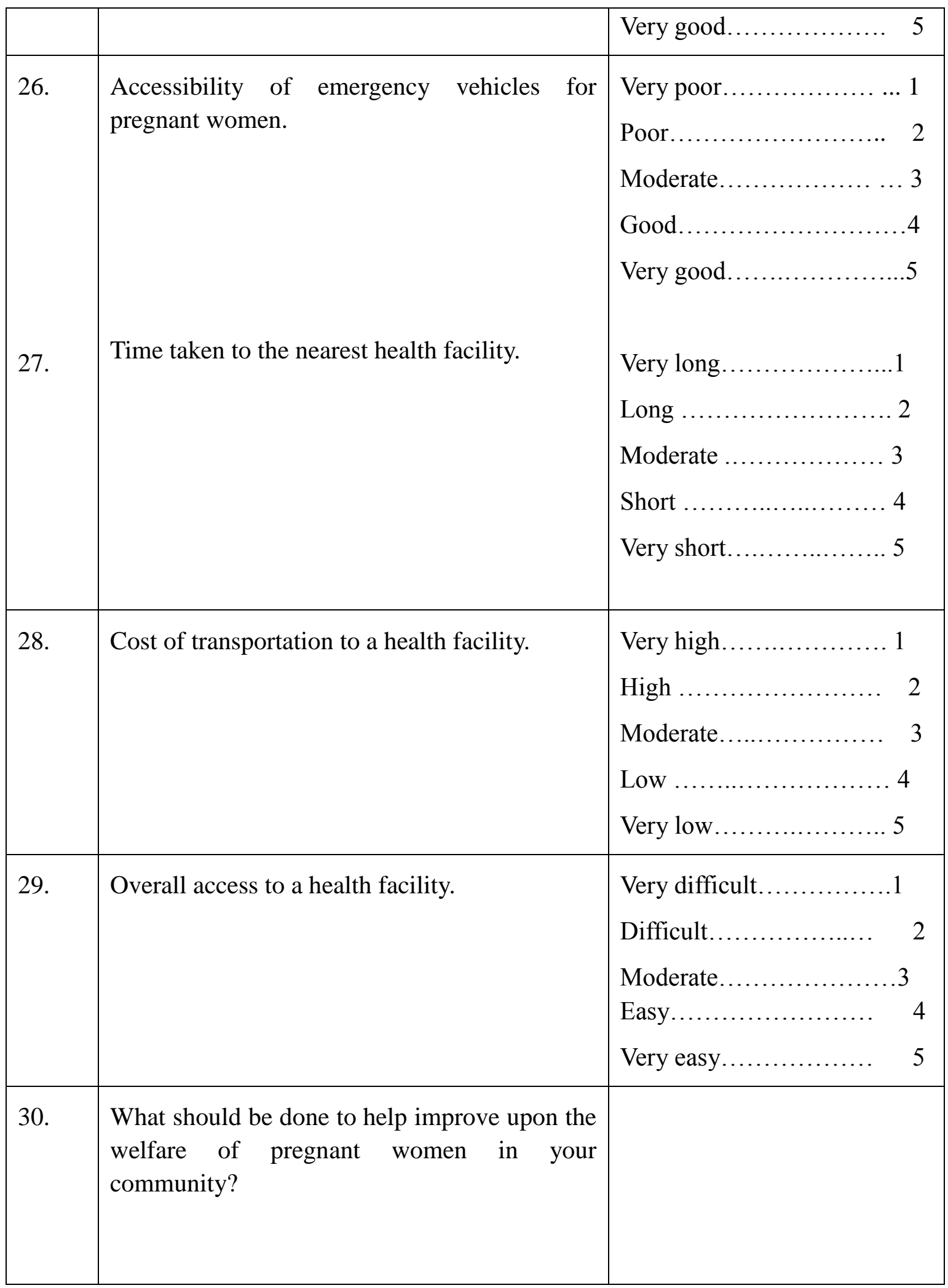

\section{Copyright Disclaimer}

Copyright reserved by the author(s).

This article is an open-access article distributed under the terms and conditions of the Creative Commons Attribution license (http://creativecommons.org/licenses/by/3.0/). 